\begin{tabular}{|l|l|l||}
\hline \multicolumn{2}{|c|}{ PublisherInfo } \\
\hline \hline PublisherName & $:$ & BioMed Central \\
\hline \hline PublisherLocation & $:$ & London \\
\hline \hline PublisherImprintName & $:$ & BioMed Central \\
\hline \hline
\end{tabular}

\title{
Small genomes are still shrinking
}

\begin{tabular}{|l|l|l||}
\hline \multicolumn{2}{|c|}{ ArticleInfo } \\
\hline \hline ArticleID & $:$ & 4434 \\
\hline \hline ArticleDOI & $:$ & $10.1186 /$ gb-spotlight-20020328-02 \\
\hline \hline ArticleCitationID & $:$ & spotlight-20020328-02 \\
\hline \hline ArticleSequenceNumber & $:$ & 100 \\
\hline \hline ArticleCategory & $:$ & Research news \\
\hline ArticleFirstPage & $:$ & 1 \\
\hline \hline ArticleLastPage & $:$ & 2 \\
\hline \hline & & RegistrationDate : 2002-3-28 \\
\hline ArticleHistory & $:$ & OnlineDate \\
\hline \hline ArticleCopyright & $:$ & BioMed Central Ltd2002-3-28 \\
\hline \hline ArticleGrants & $:$ & \\
\hline \hline ArticleContext & $:$ & 130593311 \\
\hline \hline
\end{tabular}




\section{Tudor Toma}

Email: t.toma@ic.ac.uk

Buchnera is a mutualistic intracellular symbiotic bacterium found in many aphids, and over millions of years it has experienced a dramatic decrease in genome size, retaining only those genes essential for its specialized lifestyle. In the March 19 Proceedings of National Academy of Sciences, Rosario Gil and colleagues from Universitat de Valencia, Spain, show that the Buchnera genome is still undergoing a reductive process.

Gil et al. performed physical mapping of Buchnera genomes obtained from five aphid lineages. They found that the genome size among different lineages is not conserved, but has been reduced down to 450 $\mathrm{kb}$ in some species. In addition, they showed evidence that six species of Buchnera have a genome size smaller than that of Mycoplasma genitalium, the smallest bacterial genome reported thus far $(580 \mathrm{~kb}$; Proc Natl Acad Sci USA 2002, 10.1073/pnas.062067299).

"The sequencing of these smaller genomes will give new clues about the lost genes that are essential for bacterial growth, in an attempt to define a minimal genome [the minimum number of genes necessary to support cellular life]," suggested the authors.

\section{References}

1. Gil R, Sabater-Muñoz B, Latorre A, Silva FJ, Moya A: Extreme genome reduction in Buchnera spp.: Toward the minimal genome needed for symbiotic life. Proc Natl Acad Sci USA 2002, 10.1073/ pnas.062067299., [http://www.pnas.org/cgi/content/abstract/062067299v1]

2. Universitat de Valencia, [http://www.uv.es/ uvalen/cat/]

3. Mycoplasma genitalium genome, [http://www.ncbi.nlm.nih.gov/Complete_Genomes/Mgen/] 